\title{
PENGARUH UKURAN PERUSAHAAN, FINANCIAL LEVERAGE, DIVIDEND PAYOUT RATIO, DAN NILAI PERUSAHAAN TERHADAP PERATAAN LABA
}

\author{
Yolanda Sesilia ${ }^{1}$, Achmad Zubaidi Indra ${ }^{2}$, Chara Pratami Tidespania Tubarad ${ }^{3}$ \\ ${ }^{1}$ Fakultas Ekonomi dan Bisnis Universitas Lampung \\ ${ }^{2}$ Fakultas Ekonomi dan Bisnis Universitas Lampung \\ ${ }^{3}$ Fakultas Ekonomi dan Bisnis Universitas Lampung
}

\section{Informasi Naskah}

\section{Update Naskah:}

Dikumpulkan: 19 Nov 2020;

Diterima: 2 January 2021;

Terbit/Dicetak: 24 January 2021.

\section{Keywords:}

Income smoothing, firm size, financial leverage, dividend payout ratio, and firm value.

\section{Abstract}

This study aimed to examine the effect of Firm Size, Financial Leverage, Dividend Payout Ratio, and Firm Value toward Income Smoothing in BUMN Companies Listed on Indonesia Stock Exchange. Income Smoothing measured by Index Eckel's. The Population in this study is BUMN companies listed on the Indonesia Stock Exchange in 2015-2019 Based on the purposive sampling method, the sum of a sample obtained from the population is 16 companies. Sources of data obtained from annual reports of companies listed on Indonesia Stock Exchange in 2015-2019. The analytical method for this study uses logistic regression analysis and Mann Whitney test with SPSS 21. Based on the result of the analysis showed Firm Size, Financial Leverage, Dividend Payout Ratio, and Firm Value are not influence Income Smoothing. 
Persaingan yang semakin ketat dalam dunia bisnis menuntut manajemen untuk semakin kompetitif dalam meningkatkan efisiensi dan efektivitas kinerjanya untuk mencapai tujuan perusahaan. Tujuan dalam kegiatan bisnis adalah keuntungan yang paling optimal dari usaha yang dijalankan. Tujuan kedua dari kegiatan bisnis adalah para investor menginginkan usaha yang dijalankan berjalan dalam waktu yang panjang. Lalu tujuan ketiga adalah perusahaan dibutuhkan oleh pasar atau masyarakat umum. Terakhir adalah tujuan kegiatan bisnis dapat menjadi lapangan kerja bagi masyarakat dan juga dapat membantu pemerintah dalam mengurangi angka pengangguran.

Laporan keuangan bertujuan memberikan informasi keuangan, kinerja perusahaan dan perubahan posisi keuangan, yang dapat digunakan dalam mengambil keputusan perusahaan. Laporan keuangan tidak hanya diperuntukkan bagi para manajer, tetapi juga investor, kreditur, pemerintah, dan juga masyarakat. Laporan keuangan menyajikan informasi mengenai laba perusahaan. Informasi laba yang disajikan berguna untuk menjadi penilaian dalam mengevaluasi kinerja perusahaan, menghitung kemungkinan risiko investasi, serta memperkirakan keuntungan yang akan diperoleh di masa depan (Pramono, 2013).

Manajemen menyadari pentingnya informasi dari laporan keuangan yang memberi tekanan bagi pihak manajer dan seringkali mendorong manajemen untuk melakukan praktik - praktik manajemen laba, seperti praktik perataan laba (income smoothing). Laba yang tidak mengalami banyak fluktuasi di setiap periode dianggap sebagai pencapaian yang baik. Oleh karena itu, apabila manajemen merasa fluktuasi laba tidak stabil dan memberikan risiko bagi perusahaan, maka manajer akan cenderung mengurangi fluktuasi dengan cara mengalihkan pendapatan dari tahun-tahun tinggi ke pendapatan yang lebih rendah, sehingga terjadi perataan laba. (Copeland, 1968).

Hal lainnya yang menjadi alasan mengapa manajemen mempraktikkan perataan laba, yaitu: memenuhi kepentingan principal, contohnya dengan cara meningkatkan nilai perusahaan, selain itu, dari sisi manajemen memiliki keinginan untuk memperoleh bonus dan jabatan dari perusahaan (Arfan dan Wahyuni, 2010).

Fenomena yang pernah terjadi pada perusahaan BUMN adalah manipulasi laporan keuangan PT Kimia Farma, Tbk tahun 2001. Ditemukan bahwa penyajian laporan keuangan tidak tepat sehingga laba bersihnya dibesar-besarkan menjadi Rp32,6 miliar. Selain itu, PT Indofarma juga melakukan manipulasi laporan keuangan pada tahun yang sama. Terbukti bahwa nilai barang yang sedang di proses dlebihlebihkan menjadi Rp 28,87 miliar. Hal ini menyebabkan laba bersih PT Indofarma dinilai terlalu tinggi.

Fenomena yang belum lama terjadi terdapat 3 perusahaan besar BUMN PT Garuda Indonesia (Persero) Tbk, PT Perusahaan Listrik Negara (Persero) atau PLN_dan PT Pertamina (Persero) mengalami peningkatan laba yang signifikan. Perusahaan BUMN di Indonesia mengalami permasalahan dalam laporan keuangannya dikarnakan perubahan-perubahan laba yang jauh di setiap kuartal dalam satu tahun maupun perubahan dari tahun ketahun.

Menurut penelitian yang dilakukan Santoso dkk (2012) bahwa profitabilitas yang di proyeksikan dengan ROA dan ROE, financial leverage, dan dividen menunjukkan tidak adanya pengaruh dari keempat variabel tersebut terhadap motivasi manajemen melakukan perataan laba. Sementara itu, yang mempengaaruhi praktik perataan laba adalah ukuran perusahaan dan kepemilikan institusional.

Hasil penelitian tersebut berbeda dengan hasil penelitian Pratiwi \& Damayanthi (2017) yang mengungkapkan DER berpengaruh positif karena komposisi hutang perusahaan berlebih akan menyebabkan pengeluaran yang lebih tinggi dibandingkan dengan modal sendiri. Variabel profitabilitas berpengaruh positif dan signifikan terhadap perataan laba karena laba yang tinggi mungkin tidak cukup bagi perusahaan. Dividend payout ratio berpengaruh positif dan signifikan terhadap perataan labakarena pembagian laba kepada pemilik saham dipengaruhi oleh jumlah laba ditahan, sedangkan nilai perusahaan 
berpengaruh positif dan signifikan pada perataan laba karena jika harga saham naik maka nilai perusahaan menambah kemakmuran sebesar-besarnya bagi para pemilik saham.

Dalam penelitian Lahaya (2017) dividend payout ratio dan nilai perusahaan tidak memengaruhi tindakan perataan laba, yang memengaruhi perataan laba adalah risiko perusahaan dan ukuran perusahaan. Perbedaan dengan hasil dari penelitian sebelumnya menujukkan bahwa tidak terdapat kesamaan hasil yang diperoleh dari penilitian-penelitian sebelumnya, sehingga peneliti melakukan penelitian secara mendalam mengenai faktor yang memengaruhi perataan laba. Maka penelitian ini berjudul "UKURAN PERUSAHAAN, FINANCIAL LAVERAGE, DIVIDEND PAYOUT RATIO, DAN NILAI PERUSAHAAN PADA PERATAAN LABA.

\section{B. LANDASAN TEORI DAN PENGEMBANGAN HIPOTESIS}

\section{Positive Accounting Theory}

Menurut Belkaoui (2007) positive accounting theory ada tiga hipotesis yang dapat digunakan untuk memprediksi motivasi manajemen melakukan pengelolaan laba, yaitu: hipotesis biaya politik (political cost hypothesis) menyatakan bahwa perusahaan yang besar dapat memilih metode akuntansi untuk menambah atau mengurangi laba rugi saat ini, Hipotesis rencana bonus (bonus plan hypothesis) menyatakan bahwa manajer perusahaan dengan rencana bonus lebih cenderung menggunakan metode akuntansi untuk memperbaiki laporan laba rugi saat ini, dan Hipotesis ekuitas hutang (debt covenant hypothesis) menyatakan bahwa semakin tinggi hutang ekuitas perusahaan, semakin ketat batasan perusahaan pada kontrak hutang, semakin besar kemungkinan melanggar kontrak dan semakin besar kemungkinan manajer menggunakan metode akuntansi yang meningkatkan laba.

\section{Manajemen Laba}

Menurut Sulistyanto (2008) dalam Abiprayu (2011), manajemen laba merupakan tujuan manajer perusahaan mencoba memengaruhi informasi dalam laporan keuangan untuk untuk mengelabui stakeholder yang ingin mengetahui kinerja dan kondisi perusahaan. Bentuk atau pola manajemen laba meliputi: taking a bath, income minimization, income maximization, income smoothing.

\section{Perataan Laba}

Menurut Beidleman (1973) dalam Riahi dan Belkaoui (2012) perataan laba atau income smoothing merupakan pengurangan atau fluktuasi yang disengaja dari beberapa tingkat laba saat ini yang dianggap normal oleh perusahaan. Dengan demikian perataan laba akan dilakukan jika laba aktual lebih besar dari laba normal maka laba diperkecil dan jika laba akrual yang diperoleh kurang dari laba normal, maka upaya untuk meningkatkan laba akan dilakukan.

\section{Ukuran Perusahaan}

Definisi ukuran perusahaan menurut Suwito dan Herawaty (2005) dalam Budiasih (2009) merupakan suatu skala yang digunakan untuk mengelompokkan besar kecilnya perusahaan menurut berbagai metode, antara lain: total aset, log size, nilai pasar saham, dan sebagainya. Ukuran perusahaan dapat dibedakan menjadi tiga kelompok yaitu perusahaan besar (large firm), perusahaan menengah (medium firm), dan perusahaan kecil (small firm).

Menurut Santoso dkk (2012) semakin besar sebuah perusahaan maka publik akan berfokus pada perusahaan tersebut dan perusahaan memiliki tanggungjawab yang lebih besar juga ke masyarakat. Dalam penelitian yang dilakukan oleh Budiasih (2009) dan didukung dalam penelitian Mahmud (2012) dan Santoso dkk (2012) menemukan bahwa adanya pengaruh positif ukuran perusahaan terhadap perataan laba 
dikarenakan semakin besar ukuran perusahaan, maka perusahaan akan semakin disorot publik dan pemerintah. Publik akan menyoroti tanggung jawab sosial yang diberikan dari laba yang dihasilkan sementara pemerintah akan menyoroti beban pajak yang dihasilkan perusahaan. Maka hipotesis pertama pada penelitian ini adalah:

\section{H1: Ukuran Perusahaan berpengaruh positif terhadap praktik perataan laba}

\section{Financial Leverage}

Leverage merupakan perbandingan antara hutang dengan aset yang dimiliki sebagai jaminan pelunasan hutang perusahaan. Menurut Nehemia (2015) financial leverage menunjukkan proporsi penggunaan hutang untuk membiayai investasinya. Semakin besar hutang perusahaan maka semakin besar pula risiko yang dihadapi investor sehingga investor akan meminta tingkat keuntungan yang semakin tinggi. Dengan kondisi permintaan dari investor tersebut, akan mendorong manajer melakukan praktik praktik perataan laba.

Pratiwi \& Damayanthi (2017) menyebutkan Debt to equity ratio berpengaruh positif disebabkan semakin tinggi komposisi hutang perusahaan dibandingkan dengan modal sendiri menyebabkan beban perusahaan semakin tinggi. Maka hipotesis kedua pada penelitian ini adalah:

\section{H2: Financial leverage berpengaruh positif terhadap perataan laba}

\section{Dividend Payout Ratio}

Dividend payout ratio (DPR) menurut Jogiyanto (2012) adalah rasio yang menunjukkan besarnya dividen yang dibagikan dari banyaknya laba yang diperoleh perusahaan. Dividend payout ratio merupakan proporsi dari laba bersih per satu lembar saham yang dibayarkan dalam bentuk dividen kepada pemegang saham. Untuk mendapatkan dividen yang tinggi dibutuhkan nilai saham yang tinggi dari perusahaan. seorang investor akan melihat nilai saham sebelum memutuskan untuk berinvesatasi.

Dalam penelitian Budiasih (2009) yang mengatakan bahwa dividend payout ratio berpengaruh terhadap perataan laba, hal ini didukung dalam penelitian Pratiwi dan Damayanthi (2017) yang mengatakan dividend payout ratio memengaruhi perataan laba dikarnakan pendistribusian laba kepada pemegang saham dengan memperhitungkan laba ditahan menjadi daya tarik bagi investor. Berdasarkan hal tersebut, maka hipotesis ketiga dalam penelitian ini adalah:

\section{H3: Dividend payout ratio berpengaruh positif terhadap perataan laba}

\section{Nilai Perusahaan}

Nilai perusahaan adalah harga yang calon pembeli bersedia bayar untuk harga saham perusahaan yang dijual (Husnan, 2000). Nilai perusahaan menjadi sesuatu yang dinilai sangat penting karena nilai perusahaan yang tinggi akan menunjukkan tingkat kemakmuran pemegang saham. Oleh karena itu, pemilik perusahaan cenderung akan meminta manajer untuk menaikan nilai perusahaan dan menjaga konsistensi laba di setiap periode.

Dalam penelitian Suranta dan Merdistuti (2004) adalah perusahaan yang memiliki nilai pasar yang tinggi akan cenderung untuk melakukan perataan laba karena perusahaan akan cenderung menjaga konsistensi labanya agar nilai pasar perusahaan tetap tinggi sehingga dapat menarik lebih banyak investor. Berdasarkan hal tersebut, maka hipotesis keempat dalam penelitian ini adalah:

\section{H4: Nilai perusahaan berpengaruh positif terhadap perataan laba}




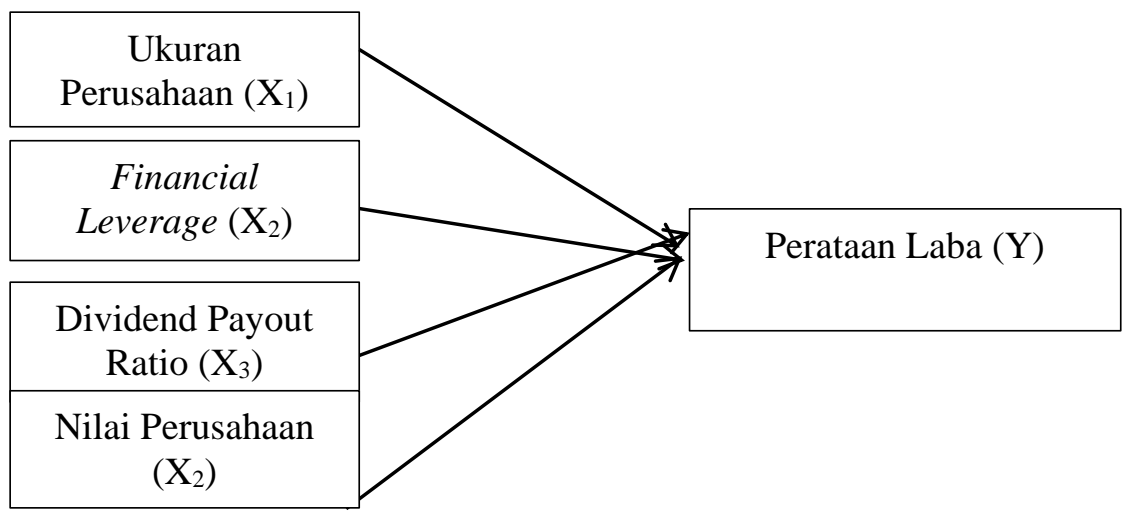

Gambar 1. Rerangka Pemikiran

\section{METODE PENELITIAN}

\section{Populasi dan Sampel}

Populasi yang digunakan dalam penelitian ini adalah BUMN yang terdaftar di Bursa Efek Indonesia pada tahun 2015-2019, sehingga diperoleh populasi sebanyak 20 perusahaan, sedangkan, pemilihan sampel dilakukan dengan menggunakan metode purposive sampling, yang merupakan metode pengambilan sampel dengan menggunakan beberapa kriteria sehingga dapat digunakan sebagai sampel.

Adapun kriteria tersebut meliputi: 1) Perusahaan BUMN yang terdaftar di Bursa Efek Indonesia serta menerbitkan laporan tahunan selama lima tahun berturut-turut selama tahun 2015-2019. 2) Perusahaan BUMN yang memberikan dividen selama tahun 2015-2019.

\section{Perataan Laba}

Pada penelitian ini, variabel dependen yang digunakan adalah Perataan laba. Perataan laba di analisis dengan indeks Eckel (1981). Selain itu, penelitian ini juga menggunakan variabel dummy dengan pengukuran 1 (satu) untuk perusahaan yang melakukan perataan laba apabila nilai dari Indeks Eckel $<1$ dan 0 (nol) untuk perusahaan yang tidak melakukan perataan laba apabila nilai dari Indeks Eckel $\geq 1$. Indeks Eckel akan membedakan perusahaan yang melakukan praktik perataan laba, yang dalam hal ini indeks laba dihitung dengan menggunakan rumus sebagai berikut:

Keterangan:

$$
\text { Indeks Eckel }=\frac{\mathrm{CV} \Delta \mathrm{I}}{\mathrm{CV} \Delta \mathrm{S}}
$$

IS= Income Smoothing

$\mathrm{CV} \Delta I=$ koefisien variasi perubahan laba

$\mathrm{CV} \Delta S=$ koefisien variasi perubahan pendapatan

Yang dalam hal ini CV $\Delta I$ atau CV $\Delta S$ dihitung dengan rumus berikut:

$$
\mathrm{CV} \Delta I \text { atau } \mathrm{CV} \Delta S=\sqrt{\frac{\sum(\Delta \mathbf{x}-\Delta \overline{\mathbf{x}})^{2}}{n-\mathbf{1}}}: \Delta \overline{\mathbf{x}}
$$

Keterangan:

$\Delta \mathrm{x}$ : perubahan penghasilan bersih/ laba

$\Delta$ : Rata- răta perubahan penghasilan bersih/laba

$\mathrm{n}$ : Banyaknya tahun yang diamati 


\section{Ukuran Perusahaan}

Dalam penelitian ini ukuran perusahaan di hitung dengan melogaritmakan total aset perisahaan. Total aset perusahaan dapat menunjukkan kekayaan yang dimiliki perusahaan. Selain itu, dengan melogaritmakan mampu menyederhanakan perhitungan.

Ukuran Perusahaan $=$ Log. Total Aset

\section{Financial Leverage}

Penelitian ini menggunakan proxy debt to total equity ratio atau DER. Menurut Syamsuddin (2006) Debt to Total Equity Ratio (DER) digunakan untuk mengukur seberapa besar jumlah ekuitas dan hutang untuk membiayai aset perusahaan. Semakin tinggi rasio DER ini berarti modal perusahaan lebih sedikit dibandingkan hutang yang harus dibayar, sehingga akan memberatkan perusahaan. Semakin kecil rasio ini, perusahaan akan dinilai semakin aman. DER dihitung dengan rumus:

$$
\text { Debt to Equity Ratio }=\frac{\text { Total Hutang }}{\text { Total Ekuitas }} \times 100 \%
$$

\section{Dividend Payout Ratio}

Dividen payout ratio menunjukkan proporsi dividen yang akan dibagikan perusahaan kepada para pemilik saham perusaaan. Perhitungan dividend payout ratio ini melakukan perbandingan antara dividen perlembar dan harga perlembar dengan rumus:

$$
\text { Dividend Payout Ratio }=\frac{\text { Dividend per share }}{\text { Earning per Share }} \times 100 \%
$$

\section{Nilai Perusahaan}

Nilai perusahaan merupakan harga yang bersedia dibayar oleh calon pembeli apabila perusahaan tersebut dijual, yang terjamin dari harga saham. Nilai perusahaan dapat di definisikan dengan Price per Book (PBV) yang merupakan rasio dari nilai pasar ekuitas perusahaan terhadap nilai buku ekuitas perusahaan dengan rumus:

$$
\text { Price per Book }=\frac{\text { Nilai Pasar }}{\text { Nilai Buku }} \times 100 \%
$$

\section{ANALISIS DAN PEMBAHASAN}

Teknik pemilihan sampel dalam penelitian ini menggunakan metode purposive sampling, yaitu menentukan sampel berdasarkan kriteria-kriteria tertentu. Jumlah perusahaan Badan Usaha Milik Negara (BUMN) yang terdaftar di Bursa Efek Indonesia (BEI) selama periode 2015-2019 dan memenuhi kriteria sampel penelitian sebanyak 16 perusahaan. Berikut rincian kriteria pengambilan sampel penelitian:

Tabel 1. Tahapan Seleksi Sampel dengan Kriteria

\begin{tabular}{lc}
\hline Kriteria Sampel & Jumlah \\
\hline Perusahaan Badan Usaha Milik Negara (BUMN) yang terdaftar di Bursa Efek Indonesia & 20 \\
(BEI) serta menerbitkan laporan tahunan selama lima tahun berturut-turut yaitu tahun 2015 & \\
sampai dengan tahun 2019. & $(4)$ \\
(-) Perusahaan yang tidak membagikan dividen secara berturut-turut & 16 \\
Jumlah perusahaan dalam periode penelitian & \\
\hline
\end{tabular}

Sumber: Data sekunder diolah 
Tabel 2. Hasil Uji Statistik Deskriptif

\begin{tabular}{cccccc}
\hline & N & Minimum & Maximum & Mean & Std. Deviation \\
\hline Ukuran Perusahaan & 80 & 3,36 & 3,55 & 3,4612 &, 05237 \\
Financial Leverage & 80 &, 11 & 11,30 & 2,9041 & 2,60486 \\
Dividend & 80 &, 05 & 2,00 &, 3839 &, 32858 \\
Nilai Perusahaan & 80 &, 23 & 11,05 & 2,1780 & 1,80891 \\
Perataan Laba & 80 &, 00 & 1,00 &, 4875 &, 50300 \\
Valid N (listwise) & 80 & & & & \\
\hline
\end{tabular}

Sumber: Output SPSS

Berdasarkan hasil analisis statistik deskriptif diperoleh hasil sebagai berikut:

1. Ukuran Perusahaan

Hasil perhitungan statistik deskriptif ukuran perusahaan diperoleh nilai minimum sebesar 3,36 oleh PT Semen Batu Raja Tbk pada tahun 2015 dan nilai maksimum sebesar 3,55 dengan perusahaan BUMN yang memiliki total aset tertinggi adalah PT Bank Rakyat Indonesia Tbk dan PT Bank Mandiri Tbk. Diperoleh nilai rata-rata (mean) sebesar 3,4612 dengan deviasi standar sebesar 0,05237 menunjukkan bahwa nilai rata-rata (mean) lebih besar dari deviasi standar $(3,4612>0,05237)$ mengartikan bahwa representasi yang buruk bagi seluruh data atau persebaran tidak merata dengan baik karena ada yang terlalu tinggi atau terlalu rendah.

\section{Financial Leverage}

Dari hasil perhitungan statistik dari debt to equity ratio diperoleh nilai minimum sebesar 0,11 yang dimiliki PT Semen Baturaja Tbk pada tahun 2015 dan nilai maksimum sebesar 11,30 dimiliki PT Bank Tabungan Negara Tbk pada tahun 2019. Hasil dari deviasi standar sebesar 2,60486 dan nilai rata rata (mean) sebesar 2,9041 yang artinya setiap Rp. 1 dari modal menjamin hutang sebesar Rp. 2,904 yang dimiliki perusahaan. Nilai debt to equity ratio yang tinggi di atas angka 1 pada perusahaan-perusahaan dalam penelitian ini menunjukkan hutang menjadi sumber utama dalam pendanaan perusahaan.

\section{Dividend Payout Ratio}

Hasil perhitungan statistik dari variabel dividend payout ratio yaitu, nilai minimum sebesar 0,05 di peroleh PT Jasamarga Tbk pada tahun 2019 dam PT Waskita Tbk pada tahun 2019 dan nilai maksimumnya sebesar 2,00 diperoleh PT Bank Rakyat Indonesia tahun 2016. Nilai rata-rata (mean) sebesar 0,3839 dengan deviasi standar sebesar 0,32858, hal ini menunjukkan rata-rata kemampuan untuk membayar dividen sangat buruk karena di bawah angka 1 atau hanya sebesar $38 \%$ dari laba bersih.

4. Nilai Perusahaan

Nilai perusahaan yang diproyeksikan dengan price book value dengan membandingkan harga buku saham dengan harga pasar saham. Hasil perhitungan statistik dari variabel nilai perusahaan yaitu, nilai minimum sebesar 0,23 dan nilai maksimumnya sebesar 11,05. Nilai rata-rata (mean) sebesar 2,1780 yang menunjukkan suatu kondisi yang baik karena suatu perusahaan memiliki harga saham yang tinggi dan deviasi standar sebesar 1,80891 yang mengartikan tingkat data PBV dalam penelitian ini memiliki tingkat variasi yang rendah karena deviasi standar PBV di bawah rata-rata (mean). 


\section{Hasil Uji Kesesuaian Model (Overall Model Fit)}

Tabel 3. Hasil Uji Menilai Keseluruhan Model

(Block Number $=0)$ Iteration History ${ }^{\mathrm{a}, \mathrm{b}, \mathrm{c}}$

Iteration $\quad-2$ Log likelihood Coefficients

\begin{tabular}{cccc} 
& & Constant \\
\hline Step 0 & 1 & 110,854 &,- 050 \\
& 2 & 110,854 &,- 050 \\
\hline
\end{tabular}

Sumber: Output SPSS

Nilai -2 Log Likelihood (-2LogL) pada blok pertama (block number $=0$ ) terlihat nilai -2LogL sebesar 110,854. Kemudian nilai 2LogL berikutnya (block number $=1$ ) ditunjukkan pada Tabel 4.8 berikut ini:

Tabel 4. Hasil Uji Keseluruhan Model

(Block Number $=1$ )

Iteration History $\mathbf{a}, \mathbf{b}, \mathbf{c}, \mathbf{d}$

\begin{tabular}{|c|c|c|c|c|c|c|c|}
\hline \multirow[t]{2}{*}{ Iteration } & & \multirow[t]{2}{*}{-2 Log likelihood } & \multicolumn{5}{|c|}{ Coefficients } \\
\hline & & & Constant & $\mathrm{X1}$ & $\mathrm{X} 2$ & X3 & X4 \\
\hline \multirow[t]{3}{*}{ Step 1} & 1 & 110,035 & 9,170 & $-2,724$ & ,008 & ,087 & , 070 \\
\hline & 2 & 110,035 & 9,285 & $-2,759$ & ,008 & ,088 & ,072 \\
\hline & 3 & 110,035 & 9,286 & $-2,759$ & ,008 & ,088 & 072 \\
\hline
\end{tabular}

Sumber: Output SPSS

Nilai -2 Log Likehood (2LogL) berikutnya (block number $=1$ ) sebesar 110. 035. Hal ini mengalami penurunan sebesar 0.819. Penurunan nilai $2 \operatorname{LogL}$ ini menunjukkan model regresi yang lebih baik atau dengan kata lain model yang dihipotesiskan fit dengan data.

\section{Koefien Determinasi}

Tabel 5. Koefisien Determinasi

\begin{tabular}{cccc}
\hline \multicolumn{3}{c}{ Model Summary } \\
Step & -2 Log & Cox \& Snell & Nagelkerke R \\
& likelihood & R Square & Square \\
\hline 1 & $110,035^{\text {a }}$ &, 010 &, 014 \\
\hline
\end{tabular}

Sumber: Output SPSS

Berdasarkan hasil output SPSS yang ditunjukkan dalam Tabel 4. 9, nilai Nagelkerke R Square adalah sebesar 0,014. Hal ini berarti variabilitas variabel dependen yang dapat dijelaskan oleh variabel independen adalah sebesar $1,4 \%$, sedangkan sisanya yaitu sebesar $98,6 \%$ dijelaskan oleh faktor-faktor lain yang tidak diteliti dalam penelitian ini.

\section{Hasil Uji Kelayakan Model Regresi}

abel 6. Kelayakan Model Regresi

Hosmer and Lemeshow Test

\begin{tabular}{|l|r|r|r|}
\hline Step & Chi-square & \multicolumn{1}{|c|}{ df } & \multicolumn{1}{c|}{ Sig. } \\
\hline 1 & 9,786 & & 8 \\
\hline
\end{tabular}


Hasil output SPSS menunjukkan bahwa nilai Chi-square sebesar 9,786 dengan signifikansi (p) sebesar 0,280. Berdasarkan hasil tersebut, jika nilai signifikansi lebih besar dari 0,05 (p>0,05) maka dapat disimpulkan bahwa model dapat memprediksi nilai yang diamati atau model dikatakan fit dengan data dan model dapat diterima sehingga model ini dapat digunakan untuk analisis lebuh lanjut.

\section{Hasil Uji Regresi Logistik}

Uji wald digunakan untuk menguji hipotesis dalam penelitian ini. Uji wald dilakukan dengan membandingkan nilai probabilitas (sig). Apabila terlihat angka signifikansi lebih kecil dari 0,05 maka koefisien regresi adalah signifikan pada tingkat 5\%. Artinya $\mathrm{H}_{0}$ ditolak dan $\mathrm{H}_{1}$ diterima, yang artinya bahwa variabel bebas mempunyai pengaruh yang signifikan terhadap variable terikat. Analisis uji regresi ini untuk menguji seberapa jauh semua variabel terikat.

Tabel 7. Regresi Logistik

\begin{tabular}{llrrrrrr}
\hline & \multicolumn{7}{c}{ Variables in the Equation } \\
& \multicolumn{1}{c}{ B } & \multicolumn{1}{c}{ S. E. } & Wald & Df & Sig. & \multicolumn{1}{c}{$\operatorname{Exp(B)}$} \\
\hline Step 1 & X1 & $-2,759$ & 6,219 &, 197 & 1 &, 657 &, 063 \\
& X2 &, 008 &, 125 &, 005 & 1 &, 946 & 1,008 \\
& X3 &, 088 &, 736 &, 014 & 1 &, 905 & 1,092 \\
& X4 &, 072 &, 137 &, 274 & 1 &, 600 & 1,074 \\
& Constant & 9,286 & 21,225 &, 191 & 1 &, 662 & 10780,909 \\
\hline
\end{tabular}

Sumber: Output SPSS

Tabel 8. Hasil Analisis Uji Mann Whitney variabel ukuran perusahaan

Test Statistics ${ }^{\mathrm{a}}$

\begin{tabular}{lr} 
& \multicolumn{1}{c}{$\begin{array}{c}\text { Ukuran } \\
\text { perusahaan }\end{array}$} \\
\hline Mann-Whitney U & 704,000 \\
Wilcoxon W & 1484,000 \\
Z &,- 922 \\
Asymp. Sig. (2-tailed) &, 357 \\
\hline
\end{tabular}

Sumber: Output SPSS

Nilai Asymp. Sig variabel ukuran perusahaan sebesar 0,357 >0,05. Jika nilai $p$ value $>0,05$ maka tidak terdapat perbedaan bermakna dari ukuran perusahaan pada perusahaan yang melakukan perataan laba maupun yang tidak melakukan perataan laba.

Tabel 9. Hasil Analisis Uji Mann Whitney variabel Financial Leverage

\begin{tabular}{lr}
\hline \multicolumn{1}{c}{ Test Statistics $^{\mathbf{a}}$} & \multicolumn{1}{c}{$\begin{array}{c}\text { Financial } \\
\text { leverage }\end{array}$} \\
\hline Mann-Whitney U & 756,000 \\
Wilcoxon W & 1536,000 \\
Z &,- 419 \\
Asymp. Sig. (2-tailed) &, 675 \\
\hline Sumber: Output SPSS
\end{tabular}

Nilai Asymp. Sig financial leverage sebesar 0,675 >0,05. Jika nilai $p$ value $>0,05$ maka tidak terdapat perbedaan dari variabel financial leverage pada perusahaan yang melakukan perataan laba maupun yang tidak melakukan perataan laba. 
Tabel 10. Hasil Analisis Uji Mann Whitney variabel Dividend Payout Ratio

\begin{tabular}{lr}
\hline \multicolumn{1}{c}{ Test Statistics $^{\mathbf{a}}$} & \multicolumn{1}{c}{ Dividend } \\
\hline Mann-Whitney U & 735,000 \\
Wilcoxon W & 1515,000 \\
Z &,- 622 \\
Asymp. Sig. (2-tailed) &, 534 \\
\hline Sumber: Output SPSS
\end{tabular}

Nilai Asymp. Sig variabel dividend payout ratio sebesar 0,534 >0,05. Apabila nilai $p$ value > 0,05 maka tidak terdapat perbedaan antara dividend payout ratio pada perusahaan yang melakukan perataan laba maupun yang tidak melakukan perataan laba.

\section{Tabel 11. Hasil Analisis Uji Mann Whitney variabel Nilai Perusahaan}

\begin{tabular}{lr}
\hline \multicolumn{1}{c}{ Test Statistics $^{\text {a }}$} & \multicolumn{1}{c}{$\begin{array}{c}\text { Nilai } \\
\text { Perusahaan }\end{array}$} \\
\hline Mann-Whitney U & 793,000 \\
Wilcoxon W & 1654,000 \\
Z &,- 063 \\
Asymp. Sig. (2-tailed) &, 950 \\
a. Grouping Variable: Perataan laba & \\
\hline
\end{tabular}

Nilai Asymp. Sig variabel nilai perusahaan sebesar 0,950 >0,05. Apabila nilai $p$ value $>0,05$ maka tidak terdapat perbedaan nilai perusahaan pada perusahaan yang melakukan perataan laba maupun yang tidak melakukan perataan laba.

\section{Pembahasan}

\section{Pengaruh ukuran perusahaan terhadap perataan laba}

Koefisien regresi logistik variabel ukuran perusahaan sebesar -2. 759 dengan tingkat signifikansi sebesar 0,657 lebih besar dari $\alpha=0,05$. Jika tingkat signifikansi lebih besar dari 0,05 maka hipotesis pertama tidak terdukung. Penelitian ini membuktikan bahwa ukuran perusahaan tidak berpengaruh signifikan terhadap perataan laba. Dibuktikan dengan uji beda Mann Whitney dengan memperoleh signifikansi sebesar 0,357 yang menunjukkan bahwa tidak ditemukannya pengaruh ukuran perusahaan pada perusahaan yang melakukan perataan laba dengan perusahaan yang melakukan perataan laba.

Hal ini tidak sejalan dengan penelitian Budiasih (2009) yang mengemukakan bahwa perusahaan besar tidak hanya memperoleh perhatian dari para investor saja, tetapi juga dari pemerintah dan masyarakat sehingga mampu menuntut manajemen untuk menjaga reputasi perusahaan. Namun, hasil penelitian ini membuktikan ukuran perusahaan besar ataupun kecil tidak memengaruhi manajemen melakukan perataan laba. Dalam penelitian ini ditemukan bahwa ukuran perusahaan tidak dapat dilihat dari total aset yang dimiliki perusahaan.

Penelitian ini mendukung Juniarti dan Carolina (2005) bahwa ukuran perusahaan tidak berpengaruh terhadap perataan laba dikarenakan besaran perusahaan tidak selamanya diidentikkan dengan banyaknya jumlah aset yang dimiliki perusahaan, namun dapat diidentikkan dengan padat karya, yaitu seberapa banyak perusahaan menghasilkan karyanya dalam suatu periode. Maka dalam penelitian ini disimpulkan bahwa ukuran perusahaan tidak cukup dengan hanya melihat total asetnya namun bisa dengan mengukur nilai pasar saham, total penjualan,total pendapatan dan lainnya. 


\section{Pengaruh financial leverage terhadap perataan laba}

Variabel financial leverage yang diproyeksikan dengan debt to equity ratio mempunyai koefisien regresi sebesar 0,008 dengan tingkat signifikansi sebesar 0,946 lebih besar dari $\alpha=0,05$. Tingkat signifikansi lebih besar dari 0,05 maka hipotesis kedua tidak terdukung. Penelitian ini membuktikan bahwa financial leverage tidak berpengaruh signifikan terhadap perataan laba. Hasil uji beda rata-rata dengan uji Mann Whitney di peroleh hasil signifikansi sebesar 0,675 yang membuktikan bahwa tidak terdapat perbedaan DER pada perusahaan yang melakukan perataan laba dan yang tidak melakukan perataan laba. Artinya tinggi atau rendah financial leverage tidak menjadi faktor pengaruh perataan laba.

Dalam Pramono (2013) dikatakan bahwa angka DER perusahaan yang semakin tinggi menunjukkan akan semakin berisiko dan berkemungkinan perusahaan tidak membayar deviden, selain itu DER yang tinggi mengurangi laba bersih dan mengakibatkan dividend payout ratio menurun. Sejalan dengan penelitian tersebut, Framita (2018) mengatakan bahwa kreditur memberikan kredit kepada perusahaan yang mempunyai rasio hutang lebih kecil dari pada modalnya dengan laba yang stabil. Namun dalam penelitian ini perusahaan yang dijadikan sampel memiliki rasio hutang yang tinggi sebagai sumber pendanaan perusahaan.

Penelitian ini tidak sejalan dengan Pratiwi \& Damayanthi (2017) yang menyebutkan DER berpengaruh positif disebabkan semakin tinggi komposisi hutang perusahaan dibandingkan dengan modal sendiri menyebabkan beban perusahaan semakin tinggi dan memotivasi manajer melakukan perataan laba. Perbedaan dengan penelitian ini dikarnakan perbedaan populasi karena pada penelitian terdahulu dilakukan pada perusahaan dengan sektor usaha yang sama seperti manufaktur sementara penelitian ini dari berbagai sektor usaha baik sektor keuangan maupun non keuangan sehingga data yang diperoleh memiliki kompleksitas yang lebih tinggi.

\section{Pengaruh dividend payout ratio terhadap perataan laba}

Variabel dividend payout ratio mempunyai koefisien regresi sebesar 0,088 dengan tingkat signifikansi sebesar 0,905 lebih besar dari $\alpha=0,05$. Tingkat signifikansi lebih besar dari 0,05 maka hipotesis ke-3 tidak terdukung. Penelitian ini membuktikan bahwa dividend payout ratio tidak berpengaruh signifikan terhadap perataan laba. Dibuktikan dengan pengujian Mann Whitney yang memperoleh hasil signifikan sebesar 0,534 berarti dividend payout ratio tidak ditemukan perbedaan antara perusahaan yang melakukan perataan laba dengan yang tidak melakukan perataan laba. Dalam penelitian ini ditemukan bahwa dividend payout ratio yang tinggi maupun rendah tidak menjadi motivasi bagi manajemen melakukan perataan laba.

Hasil dari penelitian ini sejalan dengan peneitian Lahaya ( 2017) yang mengatakan bahwa tidak berpengaruhnya dividend payout ratio terhadap perataan laba dikarnakan para investor saat ini lebih tertarik dengan return saham untuk menghindari pembayaran pajak atas dividen perusahaan. Hal lain yang menjadi faktor tidak berpengaruhnya dividen terhadap perataan laba adalah kebijakan dividen adalah bentuk keputusan bersama prinsipal dalam RUPS, sehingga manajemen enggan melakukan praktik perataan laba.

Hasil penelitian ini bertolak belakang dengan penelitian Budiasih (2009) yang mengatakan adanya pengaruh dividend payout ratio terhadap perataan laba dikarnakan semakin tinggi rasio dividend payout ratio maka manajer semakin termotivasi untuk melakukan praktik perataan laba.

\section{4. $\quad$ Pengaruh nilai perusahaan terhadap perataan laba}

Variabel nilai perusahaan yang diproyeksikan dengan price to book value mempunyai koefisien regresi sebesar 0,072 dengan tingkat signifikansi sebesar 0,600 lebih besar dari $\alpha=0,05$. Tingkat signifikansi lebih besar dari 0,05 maka hipotesis ke-4 tidak terdukung. Hasil pengujian Mann Whitney 
diperoleh hasil sebesar 0,950 yang menyatakan bahwa tidak terdapat perbedaan nilai perusahaan pada perusahaan yang melakukan perataaan laba dan yang tidak melakukan perataan laba. Penelitian ini membuktikan bahwa nilai perusahaan tidak berpengaruh signifikan terhadap perataan laba. Sebuah perusahaan dengan PBV yang tinggi maupun rendah akan melakukan perataan laba jika memang manajemen merasa memerlukannya.

Hasil penelitian ini berbeda dengan penelitian Suranta dan Merdiastuti (2004) yang mengatakan bahwa perusahaan perusahaan yang memiliki nilai pasar yang tinggi akan menjaga dan mempertahanakan konsistensi labanya tetap menarik investor. Namun, hasil tersebut bertentangan dengan penelitian Sulistiawaty (2013) yang mengemukakan bahwa nilai perusahaan tidak berpengaruh terhadap perataan laba, terlebih jika sampel penelitian memiliki nilai perusahaan yang tinggi atau di atas satu. Karena tidak ada perbedaan antara sampel perusahaan yang memiliki nilai pasar yang tinggi dengan nilai pasar yang rendah terhadap perataan laba.

Dalam penelitian ini, hanya ada tahun-tahun tertentu yang memiliki PBV di bawah 1, namun hasilnya hampir imbang antara yang melakukan perataan laba dengan yang tidak melakukan perataan laba. Dapat disimpulkan bahwa besaran nilai perusahaan tidak memengaruhi perataan laba.

\section{E. SIMPULAN DAN SARAN}

\section{Simpulan}

1. Variabel ukuran perusahaan tidak berpengaruh signifikan terhadap perataan laba. Dengan objek penelitian perusahaan BUMN, maka ukuran perusahaan tidak tepat jika hanya dilihat dari total asset yang dimiliki.

2. Variabel financial leverage tidak berpengaruh signifikan terhadap perataan laba. Berdasarkan data sampel penelitian, perusahaan dengan DER tinggi maupun DER yang rendah melakukan praktik perataan laba.

3. Variabel dividend payout ratio tidak berpengaruh signifikan terhadap perataan laba. Kebijakan dividen disepakati dalam RUPS bersama para principal sehingga tidak akan memengaruhi manajer untuk melakukan praktik perataan laba.

4. Variabel nilai perusahaan tidak berpengaruh signifikan terhadap perataan laba. Berdasarkan data sampel, nilai PBV di atas 1 maupun di bawah 1 memiliki jumlah yang imbang untuk perusahaan yang melakukan perataan laba maupun yang tidak melakukan perataan laba.

\section{Saran}

1. Penelitian selanjutnya diharapkan dapat memperluas sampel penelitian dengan mempertimbangkan penggunaan seluruh perusahaan Badan Usaha Milik Negara (BUMN) baik yang terdaftar di BEI maupun non-BEI sebagai populasi penelitian.

2. Penelitian selanjutnya dapat mempertimbangkan variabel independen lain yang dapat memengaruhi praktik perataan laba, seperti bonus plan, kepemilikan manajerial maupun variabel lainnya yang memengaruhi praktik perataan laba.

3. Penelitian diharapkan dapat mempertimbangkan perhitungan ukuran perusahaan dengan nilai saham, total penjualan atau total modal yang dimiliki perusahaan.

\section{REFERENSI}

Abiprayu, Bratas. (2011). Pengaruh Profitabilitas, Ukuran Perusahaan, Financial Leverage, Kualitas Audit, dan Devidend Payout Ratio Terhadap Perataan Laba (Studi Kasus Pada Perusahaan Manufaktur Yang Terdaftar 
di Bursa Efek Indonesia Tahun 2006-2009).

Arfan, Muhammad dan Desry Wahyuni. 2010. Pengaruh Firm Size, Winner/Loser Stock, dan Debt to Equity Ratio Terhadap Perataan Laba (Studi Pada Perusahaan Manufaktur yang Terdaftar Di Bursa Efek Indonesia). Jurnal Telaah \& Riset Akuntansi Vol. 3 (1).

Budiasih, Igan. 2009. Faktor-faktor Yang Memengaruhi Praktik Perataan Laba. Jurnal Akumtansi. Fakultas Ekonomi Universitas Udayana Bali.

Copeland,R. M. 1968. "Income Smoothing, Journal of Accounting Research", Empirical Reseacrh in Accounting, Selected studies 6 ( Supplement).

Framita, Dien Sefty. 2018. Pengaruh Return On Asset (ROA), Net Profit Margin (NPM), Debt To Eqiuty

Ratio (DER), Leverage Operasi, dan Ukuran Perusahaan Terhadap Praktik Perataan Laba pada

Perusahaan Manufaktur Sektor Industri Dasar dan Kimia yang Terdaftar di BEI. Jurnal Akuntansi, Vol 5 No. 2. Hal 107-117.

Husnan, Suad. 2000, Manajemen Keuangan Teori dan Penerapan (Keputusan Jangka Panjang, Yogyakarta: BPFE.

Jogiyanto. 2012. Teori Portofolio dan Analisis Investasi: Edisi Ketujuh. Yogyakarta. BPFE -Yogyakarta Juniarti dan Carolina. 2005. "Analisa Faktor-Faktor yang Berpengaruh Terhadap Perataan Laba (Income Smoothing) pada Perusahaan-Perusahaan Go-Public. Jurnal Akuntansi dan Keuangan Vol 7, No. 2. Hal; $148-162$

Lahaya, Ibnu. Abdi. (2017). Pengaruh Dividend Payout Ratio, Risiko Keuangan, Nilai Perusahaan, dan Ukuran Perusahaan terhadap Perataan Laba (Studi pada Perusahaan Manufaktur Sektor Industri Dasar dan Kimia Listing di Bursa Efek Indonesia). Akuntabel, 14(1)

Mahmud, Nurfarizan Mazhani. (2012). Income Smoothing and Industriak Sector. Elixir International Journal. 10248-10252.

Nehemia, Oscar. 2015. "Pengaruh Profitabilitas, Financial Leverage, Dividend Payout Ratio, dan Nilai Perusahaan Terhadap Praktik Perataan Laba(Income Smoothing. Fakultas Ekonomi. Universitas Pasundan. Bandung.

Pratiwi, Ni Wayan Piwi Indah, \& Damayanthi, I Gusti Ayu Eka (2017). Analisis Perataan Laba dan Faktorfaktor yang Memengaruhinya. E-Jurnal Akuntansi Universitas Udayana, Vol. 20(1), 496-525.

Pramono, Olivya. (2013). Analisis Pengaruh ROA, NPM, DER, dan Size terhadap Praktik Perataan Laba (Studi Kasus pada Perusahaan Manufaktur yang terdaftar di Bursa Efek Indonesia Periode 2007-2011). Jurnal Ilmiah Mahasiswa Universitas Surabaya, 2(2), 1-16.

Riahi-Belkaoui, Ahmed. 2012. Teori Akuntansi:Edisi Lima. Jakarta: Salemba Empat.

Santoso, Eko Budi dan Sherly Novia Salim,. 2012. "Pengaruh Profitabilitas, Financial Leverage, Dividen, Ukuran Perusahaan, Kepemilikan Institusional, Dan Kelompok Usaha Terhadap Perataan Laba Studi Kasus Pada Perusahaan Non-Finansial Yang Terdaftar Di Bei. ” Vol 1 pages 185-200

Sulistiyawati. 2013. "Pengaruh Nilai Perusahaan, Kebijakan Dividen, dan Reputasi Auditor Terhadap Perataan Laba." AAJ Vol. 2 pages 148-153.

Suranta, Eddy dan Pratama Puspita Merdiastuti. 2004. “Income Smoothing, Tobin's Q, Agency Problems dan Kinerja Perusahaan”. Simposium Nasional Akuntansi VII,pages 340-357. 